\title{
The Efficacy of Greater Occipital Nerve Block in Patients with Chronic Migraine
}

\section{Kronik Migrenli Hastalarda Büyük Oksipital Sinir Bloğunun Etkinliği \\ CMeltem Karacan Gölen, @Dilek Yılmaz Okuyan}

Konya Numune State Hospital, Department of Neurology, Konya, Turkey

\begin{abstract}
Background: In chronic migraines(CM), the rate of benefiting from medical treatment is relatively low, and it is known that patients use analgesics extensively. Greater occipital nerve (GON) block, have been started to be used in chronic migraine patients who were refractory to treatment. In this study, we aimed to evaluate the headache attack frequency, analgesic use, VAS (Visual Analog Scale) and MIDAS (Migraine Disability Assessment Scale) scores in the 3-month follow-up of patients we had performed a GON block in our clinic for chronic migraine refractory to medical treatment.
\end{abstract}

Material and Method: A total of $120 \mathrm{CM}$ patients were included in the study. The number of analgesics used, the number of days with pain, and the VAS and MIDAS scores were recorded before the GON block and at one and three months of treatment.

Results: There was a statistically significant $\left(p<0.001^{*}\right)$ reduction in the number of days with pain, analgesic use, and the VAS and MIDAS scores in the first and third months compared to the pretreatment baseline values in patients who had undergone a GON block. No significant differences between the first and third months.

Conclusions: After the GON block, we noted a significant reduction of headaches and improved quality of life in patients who had been experiencing severe headaches despite medical treatment. The GON block has an exceptionally high benefit rate, might be considered as a treatment option before migraines gain chronicity, patients are not exposed to an excessive medical burden and increased treatment costs.

Keywords: Headache, migraine, chronic migraine, greater occipital nerve block, pain, VAS, MIDAS, quality of life
Öz

Amaç: Kronik migrende medikal tedaviden faydalanma oldukça düşük olup, hastalarda sıklıkla yoğun analjezik kullanımı olduğu bilinmektedir. Bu nedenle periferal sinir blokajı özellikle GON blokajı tedaviye dirençli kronik migren hastalarında kullanılmaya başlanmıştır. Bu çalışmada kliniğimizde medikal tedaviye dirençli kronik migren tanısı nedeniyle GON (Greater Occipital Nerve) blokajı uyguladığımız hastalarımızın 3 aylık takiplerinde başağısı atak sıklığını, analjezik kullanımını, VAS (Vizuel Analog Skala) değerleri ve MiDAS (Migren Özürlülük Değerlendirilmesi Ölçeği) skorlarını değerlendirmeyi amaçladık

Gereç ve Yöntem: Çalışmaya 120 kronik migren hastası dahil edildi. Hastaların GON blokajı öncesi ve sonrası 1. ve 3. ayda analjezik kullanımı, ağrılı gün sayısı, VAS ve MIDAS skorları değerlendirildi.

Bulgular: GON blokajı uygulanan hastalarda ağrılı gün sayısı, analjezik kullanımı, VAS ve MIDAS skorlarında tedavi öncesi değerlerine göre 1.ve 3. ayda istatiksel olarak anlamlı $\left(p<0,001^{*}\right)$ azalma gözlenirken, 1 . ve 3. ay bulguları arasında istatiksel olarak anlamlı fark gözlenmedi.

Sonuç: Çalışmamızda medikal tedaviye rağmen günlük yaşam aktivitelerini engelleyen şiddetli baş ağrıları olan hastalarda blokaj uygulanması sonrası baş ağrısında belirgin azalma ve hayat kalitesinde iyileşme dikkati çekmiştir. Tüm çalışmalarda etkin olduğu gösterilmiş, oldukça yüksek faydalanımı olan GON blokajının, migren hastalığı kronikleşmeden, hastalar fazla medikal yüke maruz kalmadan ve tedavi maliyetleri artmadan tedavi seçeneği haline gelmesi düşünülebilir.

Anahtar Kelimeler: Baş ağrısı, kronik migren, büyük oksipital sinir blokajı

Corresponding (iletişim): Meltem Karacan Gölen, Konya Numune State Hospital Department of Neurology, Hospital Street, No:22 Selcuklu/ Konya, Turkey

E-mail (E-posta): drmeltemkaracan@hotmail.com

Received (Geliș Tarihi): 21.06.2021Ａccepted (Kabul Tarihi): 18.08.2021 


\section{INTRODUCTION}

Migraine is one of the primary headaches, manifested as headache attacks lasting for 4-72 hours, mostly localized to one half of the head, increasing in severity with physical activity, and affecting the individual's daily living activities. Chronic migraine (CM) has been included as a subheading in the migraine classification due to its characteristics. According to the diagnostic criteria of the 2018 International Classification of Headache Disorders (ICHD-3 beta) ${ }^{[1]}$, a migraine headache, present for more than three months, eight days or more in a month, and with intervals of less

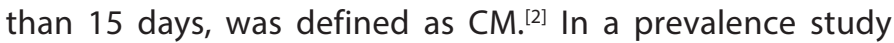
conducted in Turkey, the prevalence of CM was reported as $0.066 \%$ without medication overuse and $0.56 \%$ in newly diagnosed patients. ${ }^{[3]}$

It is known that the rate of benefiting from medical treatment is relatively low in chronic migraines, analgesics are extensively used besides frequent use of prophylactic drugs, and patients encounter disabilities because of pain. Recently, peripheral nerve blocks have been reported to be effective in particularly chronic migraine, and the greater occipital nerve (GON) block has started to be used in chronic migraine patients. It is known that in the GON block, lowconcentration local anesthetics manifest their effects by selectively blocking sensory nerve fibers to provide improvement in painful conditions.

In the study conducted by Caputi et al., reductions in headache duration, frequency, and severity for six months were reported in patients in whom the supraorbital and GON blocks were performed. ${ }^{[4]}$ Peripheral nerve blocks technically involve the blockage of trigeminal nerve branches such as supraorbital, supratrochlear, auriculotemporal nerves in addition to the greater and smaller occipital nerve blocks. In migraine patients, the GON block is the most preferred method, with studies most frequently conducted on its effectiveness. ${ }^{[5]}$ The GON block's effect is known to be via the trigeminovascular system. Conducted studies have emphasized a functional connection between the caudal trigeminal nucleus and the upper cervical segments. ${ }^{[6,7]}$ When the GON block is performed, the injected anesthetic substance creates modulation by blocking afferent stimuli at the field innervated by the nerve and preventing sensitization at the $\mathrm{C} 2$ and $\mathrm{C} 3$ dorsal horn convergence neurons. ${ }^{[5]}$

This study aimed to evaluate the headache attack frequency, analgesic use, VAS (Visual Analog Scale) and MIDAS (Migraine Disability Assessment Scale) scores in the 3-month followup in patients in whom we had performed a GON block for chronic migraine refractory to medical treatment.

\section{MATERIAL AND METHOD}

A total of 120 chronic migraine patients, aged between 18-65 years, admitted to the Neurology Outpatient Clinic between January 2017 and June 2019 were included in the study.
The patients diagnosed with chronic migraine following the international classification for headaches were reviewed, and previous data were recorded. The patients who had undergone GON block were informed about the procedure in detail, and then, their consent was obtained and archived. The study's inclusion criterion was to be a chronic migraine patient who was refractory to treatment (refractory to treatment should be defined) and had not benefited from medical treatment options. Due to the frequency of pain in patients with chronic migraine, treatment-resistant headaches ocur as a results of excessive use of drugs such as triptan, ergotamine, and opioids more than 8 days a month, and analgesics more than 15 days a month. ${ }^{[1]}$ Patients were using analgesic, ergot, triptan derivatives for attack treatment, beta-blockers, calcium channel blockers, antidepressant derivatives, topiramate group-antiepileptic treatments, and their combinations for prophylaxis.

Patients with an acute pathology or space-occupying lesion identified by cranial imaging, pregnant or breastfeeding patients, those with a history of malignancy, major psychiatric disorders, bleeding diathesis, those receiving anticoagulant treatment with coumadin and its derivatives, those allergic to local anesthetics, patients who had undergone cervical or cranial surgery, patients with neuromuscular dysfunctions, and those with infection at the procedure site were excluded from the study.

Patients' sterilization and emergency response conditions were provided. After cleaning the intervention area with an antiseptic solution, the occipital artery located at $1 / 3$ medial to the imaginary line between the occipital protuberance and mastoid process was palpated. The needle was inserted and withdrawn when the bone was reached, aspirated to check whether it was in the artery, and then $1.5 \mathrm{ml}$ of $2 \%$ lidocaine was administered. A $13 \mathrm{~mm}, 26$-gauge (G) was used for the procedure. Compression was applied after the injection. The patient was followed-up for approximately 30 minutes. The blockade procedure was bilaterally performed for six sessions, once a week in the first month and once a month in the second and third months. The VAS scores, attack frequency, attack duration, analgesic requirements before the procedure were recorded together with the 1-month and 3-month data.

\section{Ethical approval}

Approval was obtained from the Local Ethics Committee (Protocol No: 2021- 032) and the Ministry of Health for this retrospective study.

\section{Statistical Analysis}

The Shapiro Wilk test tested the normality of the distribution of continuous variables. The Freidman test and Dunn multiple comparison tests were used to compare nonnormal data across the three time points. Statistical analysis was performed with SPSS for Windows version 24.0, and a p-value $<0.05$ was considered statistically significant. 


\section{RESULTS}

One hundred twenty chronic migraine patients who had undergone GON block were included in the study. The mean age of these patients was $42.68 \pm 7.14$ years. Of the patients, $102 / 120$ (85\%) were female, and 18/120 (15\%) were male. The patients' mean pain duration was $11.63 \pm 5.66$ hours. $17 / 120(14.2 \%)$ patients described pre-headache aura. The demographic and clinical characteristics of the patients were presented in Table 1.

The number of days with pain, the number of analgesics used per month, the VAS and MIDAS scores before and one and three months after the treatment were recorded. With the GON block, the number of days with pain regressed from its pre-treatment value of 8.5 [8-12] to 4 [3-4] at the 1st month and 3 [2-4] at the 3rd month. The number of analgesics used monthly by the patients was 14 [10-16] before treatment, 5.5 [4-6.5] at the 1st month, and 6 [5-7] at the 3rd month. The VAS score regressed

Table 1. Demographic and clinical characteristics of the patients

\begin{tabular}{|c|c|c|c|}
\hline \multirow{2}{*}{\multicolumn{2}{|c|}{ Variables }} & \multicolumn{2}{|c|}{ Descriptive Statistics $(n=120)$} \\
\hline & & Mean士SD & Median (Min-Max) \\
\hline \multicolumn{2}{|c|}{ Age (years) } & $42.68 \pm 7.14$ & $43(25-64)$ \\
\hline \multirow{2}{*}{\multicolumn{2}{|c|}{ Duration (hours) }} & $11.63 \pm 5.66$ & $10.5(3-24)$ \\
\hline & & $\mathbf{n}$ & $\%$ \\
\hline \multirow{2}{*}{ Gender } & Male & 18 & 15.0 \\
\hline & Female & 102 & 85.0 \\
\hline \multirow{2}{*}{ Aura } & Present & 17 & 14.2 \\
\hline & Absent & 103 & 85.8 \\
\hline
\end{tabular}

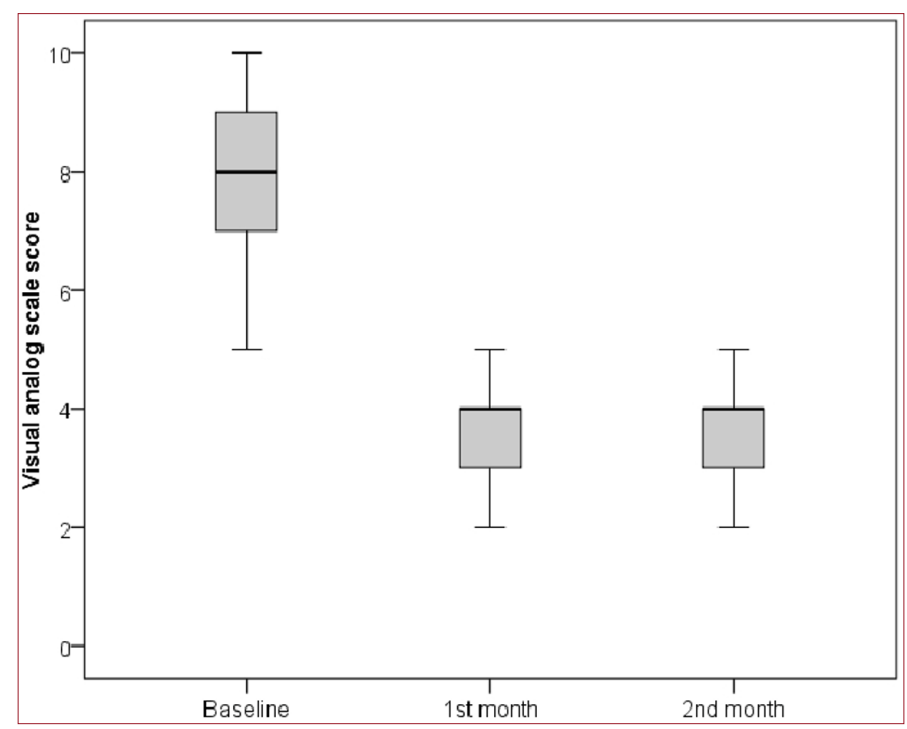

Figure 1. Comparison of VAS scores among three different time points from its pre-treatment value of 8 [7-9] to 4 [3-4] at the 1st and $3 \mathrm{rd}$ months. The MIDAS score also regressed from its pretreatment value of 4 [3-4] to 2 [1.5-2] at the 1st and 3rd months. Significant reductions were observed regarding the number of days with pain, analgesic use, and the VAS and MIDAS scores when the 1st-month and 3rd-month values were compared to the pre-treatment baseline values $\left(p<0.001^{*}\right)$. There were no statistically significant differences between the 1st-month and 3rd-month values (Table 2) (Figures 1, 2, and 3).

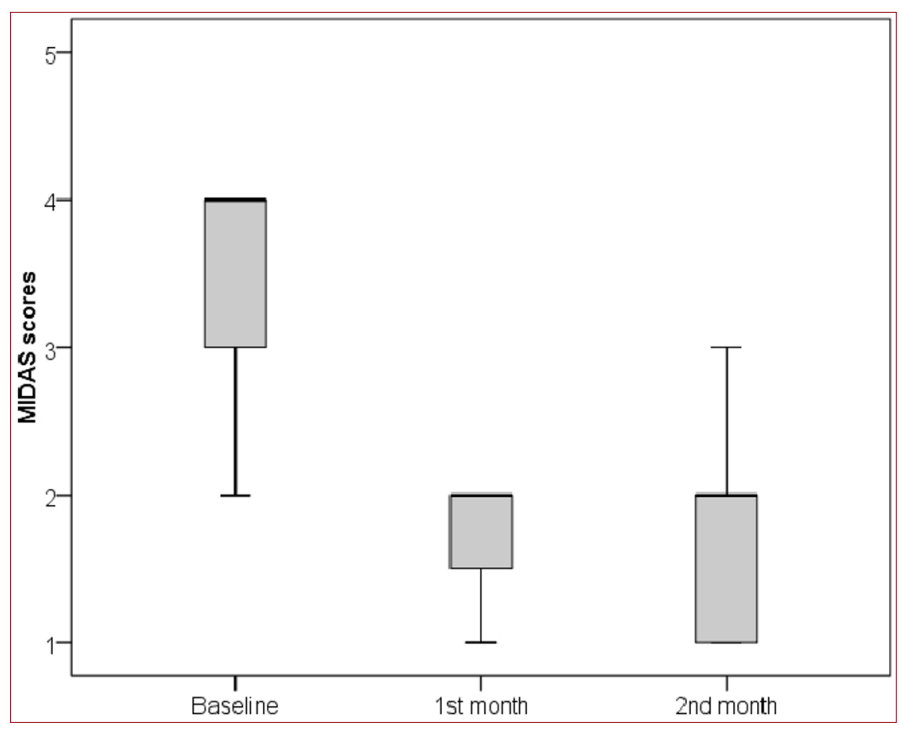

Figure 2. Comparison of MIDAS scores among three different time points

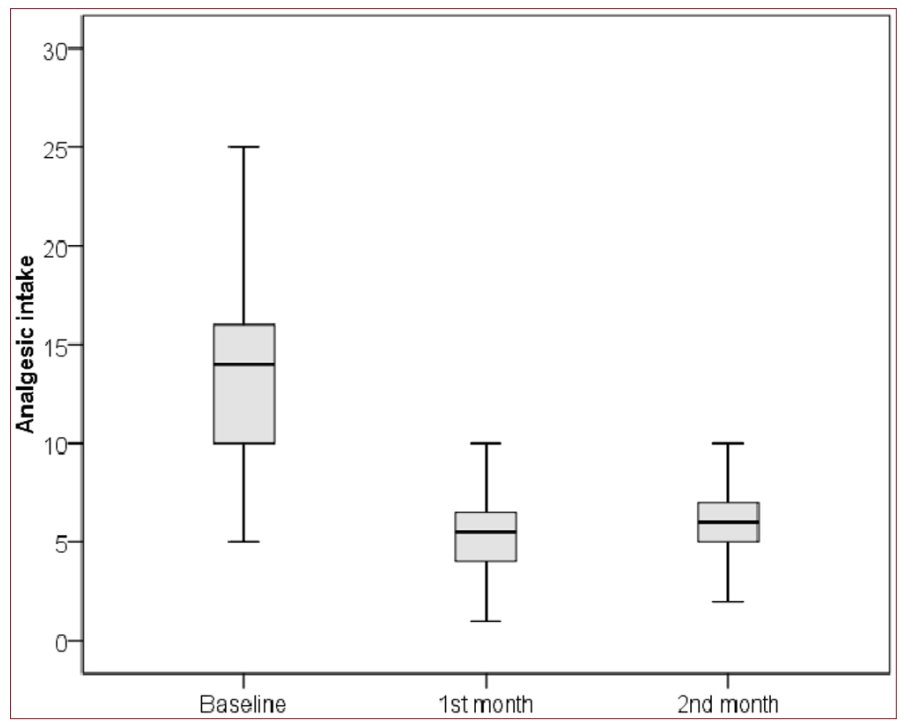

Figure 3. Comparison of analgesic use among three different time points Table 2. Clinical findings related to migraine during follow-up

\begin{tabular}{|c|c|c|c|c|c|c|}
\hline \multirow[b]{2}{*}{ Variable } & \multirow{2}{*}{$\begin{array}{c}\text { Baseline Median } \\
{[25 \%-75 \%]}\end{array}$} & \multirow{2}{*}{$\begin{array}{c}\text { 1st-month } \\
\text { Median [25\%-75\%] }\end{array}$} & \multirow{2}{*}{$\begin{array}{c}\text { 3rd-month } \\
\text { Median [25\%-75\%] }\end{array}$} & \multicolumn{3}{|c|}{ P-value } \\
\hline & & & & $\begin{array}{c}\text { 1st-month vs. } \\
\text { Baseline }\end{array}$ & $\begin{array}{c}\text { 3rd-month vs. } \\
\text { Baseline }\end{array}$ & $\begin{array}{c}\text { 1st-month vs. 3rd- } \\
\text { month }\end{array}$ \\
\hline Number of days with pain & $8.5[8-12]$ & $4[3-4]$ & $3[2-4]$ & $0.001^{*}$ & $0.001^{*}$ & 0.439 \\
\hline Analgesic use & $14[10-16]$ & $5.5[4-6.5]$ & $6[5-7]$ & $0.001^{*}$ & $0.001^{*}$ & 0.220 \\
\hline VAS score & $8[7-9]$ & $4[3-4]$ & $4[3-4]$ & $0.001^{*}$ & $0.001^{*}$ & 0.949 \\
\hline MIDAS score & $4[3-4]$ & $2[1-2]$ & $2[1-2]$ & $0.001^{*}$ & $0.001^{*}$ & 0.897 \\
\hline
\end{tabular}




\section{DISCUSSION}

Peripheral nerve blocks have recently become a preferable treatment option for primary headaches' acute and preventive treatments. Numerous randomized, controlled studies have shown that the GON block was effective. ${ }^{[4,8,9]}$ Its contributions to patient satisfaction, daily activities, and treatment costs are too significant to be ignored, mainly due to improvements in migraine treatments. There were statistically significant reductions in our study when the first and third-month values were compared to the pre-treatment values regarding the days with pain, analgesic use, VAS, and MIDAS scores in 120 patients in whom we had performed a GON block (Figures $\mathbf{1}$ and $\mathbf{2}$ ).

In many studies, it has been shown that significant improvements occurred with a GON block, injecting a local anesthetic substance, and steroids in migraines of resistant patients who were unresponsive to prophylactic treatment. ${ }^{[4-}$ ${ }^{8]}$ Caputi et al. performed GON and supraorbital blocks using bupivacaine and determined decreasing headache severity in $85 \%$ of their patients. This study determined significant pain severity reductions when we compared the periods before and after the treatment.

The American Headache Society made practical recommendations regarding peripheral nerve and GON blocks in 2013; however, they stated that a consensus had not been reached on the amount to be administered and the repetition frequency since there were not enough randomized, controlled studies. ${ }^{[10]}$ Numerous studies have been conducted on the effectiveness and use of the GON block in primary headaches to clarify such issues and determine the boundaries; however, standardization has not been yet achieved, and in most studies, different options were preferred regarding the administration technique, drug preference, and dosage. ${ }^{[9,11,12]}$

Lidocaine and bupivacaine are commonly preferred in peripheral nerve blocks. We preferred lidocaine in our patients because of its shorter half-life when compared to bupivacaine. Local anesthetics create a reversible blockade in sodium channels of nerve fibers and provide efficient control by causing depolarization in demyelinated $\mathrm{C}$-fibers and myelinated A-fibers, which play roles in pain signal transmission. Since pain control's duration is longer than the administered local anesthetic agent's half-life, pain control has been considered to be associated with central modulation. Corticosteroids may be preferred for treatment from time to time to prolong the block duration. Even though less common in chronic migraine patients, corticosteroids have been preferred particularly for the treatment of cluster headaches, and they were determined to be more efficacious. ${ }^{[13]}$ The corticosteroids' long-term effects are unknown. Corticosteroids are known to inhibit proinflammatory cytokines' synthesis and release and suppress inflammation. Moreover, they provide efficient pain control through membrane stabilization, reversible inhibition of nociceptive $\mathrm{C}$-fibers, and modulation of nociceptive input to the substantia gelatinosa. ${ }^{[5,14]}$

Numerous studies have been conducted on local anesthetics' effectiveness, superiorities to each other, and combination treatments with steroids. Gül et al. compared bupivacaine and saline and determined that the 2-month and 3-month VAS scores were significantly superior to those of the placebo group. ${ }^{[15]}$ When $0.25 \mathrm{ml}$ of lidocaine $0.5 \%$ was compared to $2.5 \mathrm{ml}$ of bupivacaine $0.5 \%$ and methylprednisolone, it was determined that their efficacies were not superior to each other. Studies on steroids' addition to treatment have shown that steroids did not contribute. ${ }^{[12,16,17]}$

There is no standardization regarding unilateral or bilateral GON block applications, and the block is performed on an optional basis. The study comparing unilateral and bilateral GON blocks' efficacies reported no difference between them. ${ }^{[18]}$ We preferred to perform bilateral GON blocks in our method.

Single block or repeated nerve blocks? Numerous studies have reported that repeated nerve blocks were more effective than single blocks. ${ }^{[16,18-21]}$ In our clinic, we preferred to perform six sessions of blocks in total, once a week in the first month and once a month in the second and third months. The treatment responses of patients in whom a GON block was performed together with prophylaxis were compared to those in whom only a GON block was performed, and no significant differences were determined between the two groups regarding the headache duration and attacks. Most of our patients had been receiving prophylactic treatment, and some of them stated that their requirement for prophylactic treatment had decreased in later treatment stages, and they had quit their medications. We determined significant reductions in patients' analgesic requirements in the course of treatment (Figure 3). The GON block is reliable for patients; however, vasovagal syncope, temporary numbness at the injection site, and particularly when combined with steroids, alopecia, and cutaneous atrophy were reported. ${ }^{[9]}$ No significant side effects were observed during and after the GON block in our study.

Our study had various limitations. Our study's shortcomings were its small sample size, absence of a control group, and our inability to follow up the patients for a longer duration. Prospective, randomized, and placebo-controlled future studies with longer duration and larger sample sizes are required.

\section{CONCLUSION}

Chronic migraine headache is a disorder restricting daily living activities despite medical treatments, adversely affecting patients' quality of living. The recently used GON block has brought a new perspective to both acute and chronic migraine treatments. The GON block has become an easily applicable, preferred method with proven efficacy 
and few side effects in chronic migraine patients. Besides increasing the chronic migraine patients' quality of life, it also reduces chronic drug consumption, related side effects, and treatment costs. The GON block, the efficacy of which has been shown in numerous studies and which has an exceptionally high benefit rate, might be considered as a treatment option before migraines gain chronicity, patients are not exposed to an excessive medical burden, and increased treatment costs.

\section{ETHICAL DECLARATIONS}

Ethics Committee Approval: Approval was obtained from the Local Ethics Committee (Protocol No: 2021- 032) and the Ministry of Health for this study.

Informed Consent: All patients signed the free and informed consent form.

Referee Evaluation Process: Externally peer-reviewed.

Conflict of Interest Statement: The authors have no conflicts of interest to declare.

Financial Disclosure: The authors declared that this study has received no financial support.

Author Contributions: All of the authors declare that they have all participated in the design, execution, and analysis of the paper, and that they have approved the final version.

\section{REFERENCES}

1. [Anonym] Headache Classification Committee of the International Headache Society (IHS) The International Classification of Headache Disorders, 3rd edition. Cephalalgia 2018;38:1-211.

2. Lipton RB, Silberstein SD. Episodic and chronic migraine headache:breaking down barriers to optimal treatment and prevention. Headache 2015;55 Suppl 2:103-22.

3. Baykan B, Ertas M, Karli N et al. Migraine incidence in 5 years:a populationbased prospective longitudinal study in Turkey. J Headache Pain 2015;16:103.

4. Caputi CA, Firetto V. Therapeutic blockade of greater occipital and supraorbital nerves in migraine patients. Headache 1997;37:174-9.

5. Inan LE, Inan N, Unal-Artik HA, et al. Greater occipital nerve block in migraine prophylaxis:Narrative review. Cephalalgia 2019;39:908-20.

6. Kerr FW, Olafson RA. Trigeminal and cervical volleys. Convergence on single units in the spinal gray at C-1 and C-2. Arch Neurol 1961;5:171-8.

7. Bartsch T, Goadsby PJ. Stimulation of the greater occipital nerve induces increased central excitability of dural afferent input. Brain 2002;125:1496509.

8. Ashkenazi A, Young WB. The effects of greater occipital nerve block and trigger point injection on brush allodynia and pain in migraine. Headache 2005;45:350-4.

9. Afridi SK, Shields KG, Bhola R et al. Greater occipital nerve injection in primary headache syndromes--prolonged effects from a single injection. Pain 2006;122:126-9.

10. Blumenfeld A, Ashkenazi A, Napchan $U$ et al. Expert consensus recommendations for the performance of peripheral nerve blocks for headaches--a narrative review. Headache 2013;53:437-46.

11. Saracco MG, Valfre W, Cavallini M et al. Greater occipital nerve block in chronic migraine. Neurol Sci 2010;31 Suppl 1:179-80.

12. Ashkenazi A, Matro R, Shaw JW et al. Greater occipital nerve block using local anaesthetics alone or with triamcinolone for transformed migraine:a randomised comparative study. J Neurol Neurosurg Psychiatry 2008;79:415-7.
13. Ambrosini A, Vandenheede M, Rossi P et al. Suboccipital injection with a mixture of rapid- and long-acting steroids in cluster headache:a doubleblind placebo-controlled study. Pain 2005;118:92-6.

14. Tetzlaff JE. The pharmacology of local anesthetics. Anesthesiol Clin North Am 2000;18:217-33.

15. Gul HL, Ozon AO, Karadas $\mathrm{O}$ et al. The efficacy of greater occipital nerve blockade in chronic migraine:A placebo-controlled study. Acta Neurol Scand 2017;136:138-44.

16. Dilli $E$, Halker R, Vargas B et al. Occipital nerve block for the short-term preventive treatment of migraine:A randomized, double-blinded, placebo-controlled study. Cephalalgia 2015;35:959-68.

17. Kashipazha D, Nakhostin-Mortazavi A, Mohammadianinejad SE et al. Preventive effect of greater occipital nerve block on severity and frequency of migraine headache. Glob J Health Sci 2014;6:209-13.

18. Unal-Artik HA, Inan LE, Atac-Ucar C et al. Do bilateral and unilateral greater occipital nerve block effectiveness differ in chronic migraine patients? Neurol Sci 2017;38:949-54.

19. Takmaz SA, Inan N, Ucler S et al. Greater occipital nevre block in migraine headache:Preliminary results of 10 patients. Ağrı 2008;20:47-50.

20. Okmen K, Dagistan Y, Dagistan E et al. Efficacy of the greater occipital nerve block in recurrent migraine type headaches. Neurol Neurochir Pol 2016;50:151-4.

21. Ruiz Piñero $M$, Mulero Carrillo $P$, Pedraza Hueso MI et al. Pericranial nerve blockade as a preventive treatment for migraine:Experience in 60 patients. Neurologia (Barcelona, Spain) 2016;31:445-51. 